\title{
"Korangadu"- Traditional Dry land Grass Farming System
}

\author{
N. Bharathy*, K. Sivakumar, V. Ramesh, D. Anandha Prakash Singh, \\ K. Chinnamani and A. Clement Ebenezer Henry
}

\begin{abstract}
Department of Livestock Production and Management, Veterinary College and Research Institute, Tamil Nadu Veterinary and Animal Sciences University, Namakkal - 637 002, Tamil Nadu, India
\end{abstract}

*Corresponding author

\begin{tabular}{l} 
Ke y w o r d s \\
$\begin{array}{l}\text { Korangadu, Three } \\
\text { tier, Grazing system }\end{array}$ \\
Article Info \\
$\begin{array}{l}\text { Accepted: } \\
\text { 26 July } 2018 \\
\text { Available Online: } \\
\text { 10 August } 2018\end{array}$ \\
\hline
\end{tabular}

\section{Introduction}

In India, grazing lands are around 12 million hectares which constituted the main grazing resources for the huge livestock population (512.05 million). But the productivity of the grazing lands is low due to over grazing and poor management. There is urgent need to improve the productivity of community grazing lands through sowing mixed stand of grasses and legume, increase grazing period and plantation of fodder trees on grazing
In India, grazing lands are around 12 million hectares which constituted the main grazing resources for the huge livestock population (512.05 million). But the productivity of the grazing lands is low due to over grazing and poor management. There is urgent need to improve the productivity of community grazing lands through sowing mixed stand of grasses and legume, increase grazing period and plantation of fodder trees on grazing lands. Korangadu pasture a private pasture land and a time tested model maintained by the farmers and it is the major source of feeding on zero budgets. Korangadu typically consists of a mixture of grass, legume and tree species including annual and perennials. It has predominantly three major species of flora, which are spatially in three tiers. The lower tier is grown with kolukattai grass (Cenchrus sp.), an upper tree species include Velvel (Acacia leucophloea) and land is fenced with thorny shrub locally called as Mullu Kiluvai (Commiphora berryii) as live fence makes up the middle tire. Once established pasture land with tree fodder will serve for 3-5 years with less labour and investment. Even the lands covered grove, waste lands, porampok lands may be converted into pasture land and the animals may be allowed to graze. This is comparatively cheaper than harvesting and chaffing the fodder to feed the animals. 
and fenced with hedges of Balasmodendron berryi. It exists in more than 500 villages in a contiguous area of about 50,000 ha in laterite red soil area where annual rainfall is about 600 - $675 \mathrm{~mm}$. This grassland area is known for the breeding tract of Kangayam breed of cattle, Mayilambadi and Mecheri breed of sheep, local buffaloes and goats and for the indigenous "Malaimadu" cattle that are known for good quality plough and draught.

The grassland is conveniently divided into paddocks of 1.5 - 10 ha depending upon the wealth status or ownership of the farmers. Average korangadu land holding size 16.1 percent of the total number of land holdings covers 51.2 percent of the area with a holding of over 4 ha. It also provides livelihood survival for local communities who are depending upon livestock keeping.

\section{Flora in Korangadu}

Korangadu typically consists of a mixture of grass, legume and tree species including annual and perennials. It has predominantly three major species of flora, which are spatially in three tiers. The lower tier is grown with kolukattai grass (Cenchrus sp.), an upper tree species include Velvel (Acacia leucophloea) and land is fenced with thorny shrub locally called as Mullu Kiluvai (Commiphora berryii) as live fence makes up the middle tire.

\section{Establishment of Korangadu pastureland}

During summer season, the land to be converted for Korangadu has to be ploughed. Sowing of Cenchrus has to be carried out during September - October. In order to cover 1 acre about $15 \mathrm{~kg}$ of Cenchrus, which has a tussock density of $18-25$ per $\mathrm{m}^{2}$, will be sufficient and such seeds are harvested from the already established pastureland. Reseeding with seeds of Cenchrus is done to boost the forage yield in subsequent years. Harvesting of seeds will be in the month of January February. This grass can also be mixed with Phaseolus trilobus, a crop that provides a very nutritious feed and Horse gram seeds at the rate of about $10 \mathrm{~kg}$ each for 1 acre. These grassland witnesses two flushes of flash growth per year, the major one in September and the minor one in May - June.

\section{In summer}

Protection to the pastureland is given by live fencing by planting cuttings of Commiphora berryii. The cutting of Commiphora shrubs should be about 4' length stumps with a thickness of 3 inches. These stumps are planted in 1 feet depth. Every year the established fence has to be maintained by proper gap filling with fresh cuttings of Commiphora and any such new plantings are to be performed only in the month of June July, (Roy A.K. and Singh J.P. 2013).

\section{Fencing with Commiphora berryii}

In Korangadu pasture land, Acacia tree grows naturally and usually seeds of Acacia germinate from the animal dung. When cattle and sheep relish the pods of Acacia the seeds are passed undigested and spread through the dung. Farmers usually maintain optimum population of Acacia tree; population will be around $20-25$ trees per acre. A tree will yield around 40 - $50 \mathrm{~kg}$ of pod (crude protein $14.86 \%$ ) and it not only serves as good feed during summer but also provide shade to the animals at mid-day (Roy and Singh, 2013). As there is no rainfall during summer months, the growth of the grass is poor or almost nonexistent and at that time, falling pods of Acacia tree will provide good fodder for animals. Whenever summer rains or unseasonal rains occur, this pastureland will have regrowth of vegetation and thereby serve as fodder source for livestock. 


\section{Grazing system}

Animals are not permitted to graze in first year after sowing, but are allowed in the second year of establishment. About one month time will be allowed after rain for the grass to germinate and attain required growth and after that, animals are allowed for grazing. From mid-June to mid-September and from October to January the animals remain on the pasture alone on rotational basis between various paddocks based on the availability of fodder. Grazing will be from morning to evening.

They are not provided with any supplementary feed. The excess fodder is harvested and stored as hay for feeding the animals during off-season. Farmers construct water troughs in the individual plots for providing drinking water for the animals. Recycling of nutrients through animal droppings occurs; external application of fertilizer on the grassland is unheard of. The growth of different local fodder species also spread in such a manner that it is likely to support the partial grazing of animals at least during 8-10 months in a year. From the field the excess pods will be collected and stored (Jayanthi and Mynavathi, 2012). Such pods will be mixed with sorghum seeds to feed lambs. Each lamb will take about
$1 / 2 \mathrm{~kg}$ of such mixture and it is fed in the morning time.

The ownership pattern of livestock in the Kangayam grassland indicates that 70 percent of the farmers own 1 to 4 cattle or buffalo, 65 percent own 15 or more sheep and 85 percent of the farmers do not own any goats.Four hectares of "Korangadu" grass land is sufficient to maintain 2 adult cows plus 4 calves or 40 sheep or 6 buffaloes or 20 goats. (Kumar et al., 2011)

SWOT analysis of establishing and maintaining of Korangadu pasture (Akila and Bharathy, 2016)

\section{Strength}

Availability of nutritious fodder throughout the year if monsoon is good

Protein rich pods from Acacia trees

Availability of further greens spread in the live fence of Commiphora berryii

Less investment

Easy maintenance and more profitable

\section{In summer}

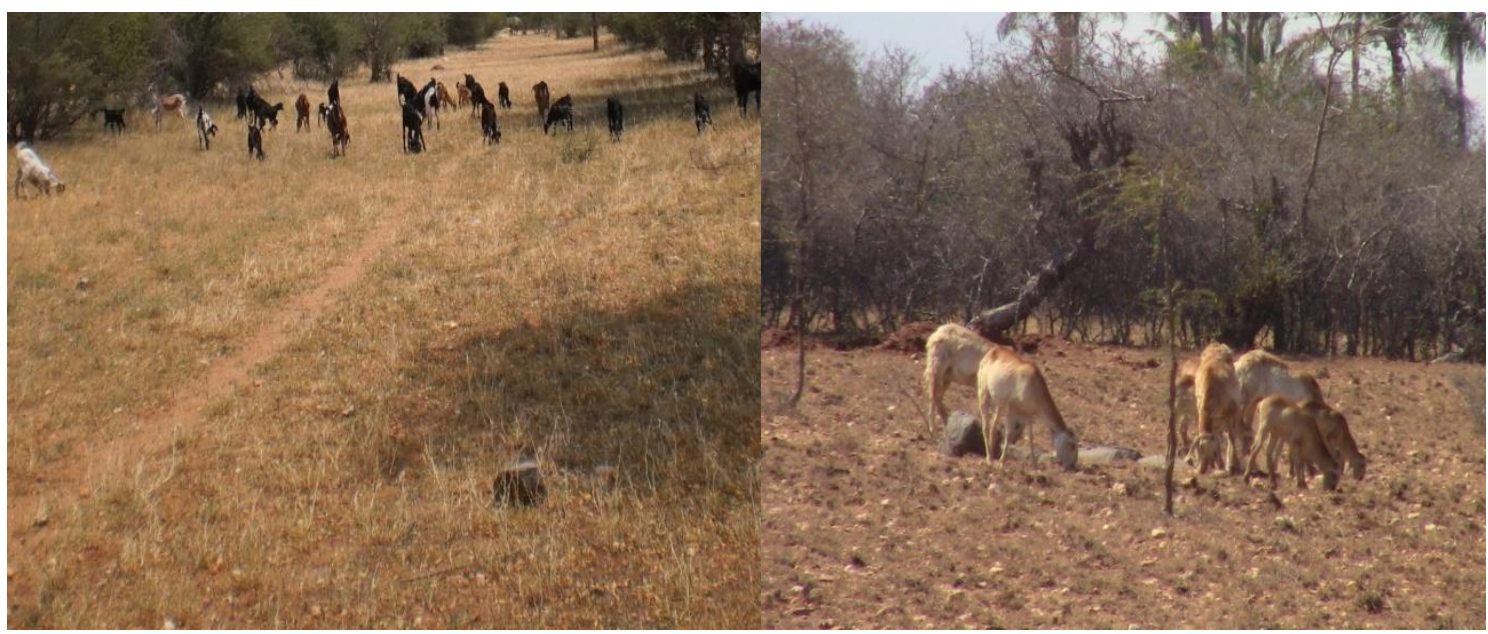




\section{Fencing with Commiphora berryii}

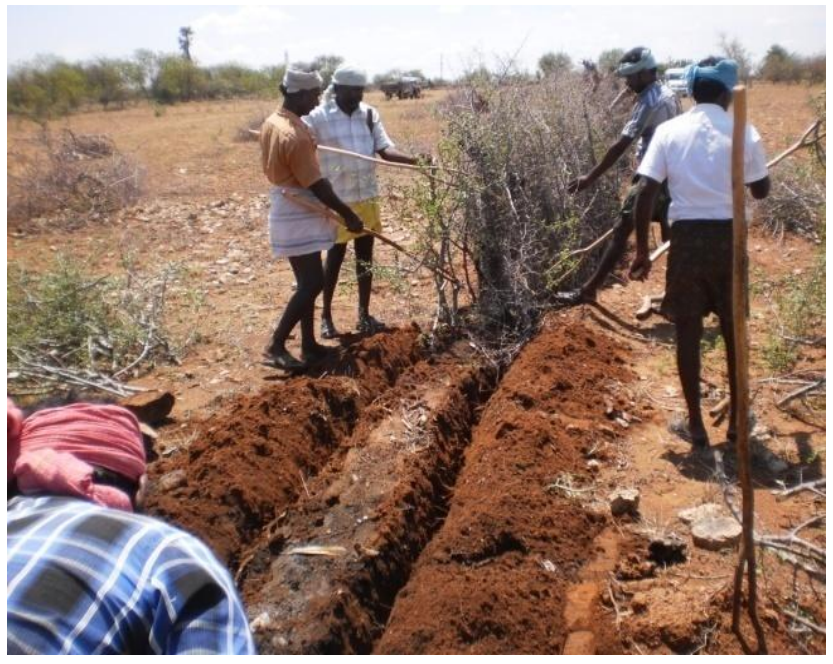

Growth after 2weeks in conventional irrigation Regrowth of vegetation during rainy season

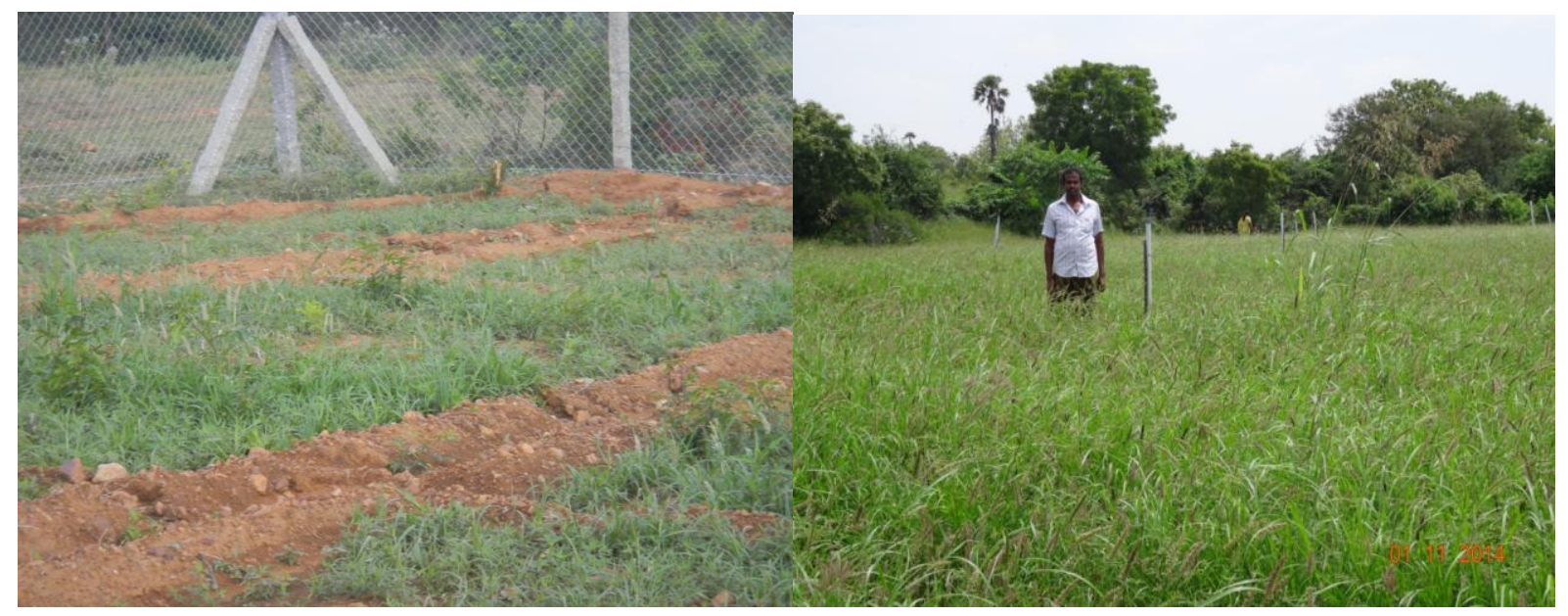

Grazing system

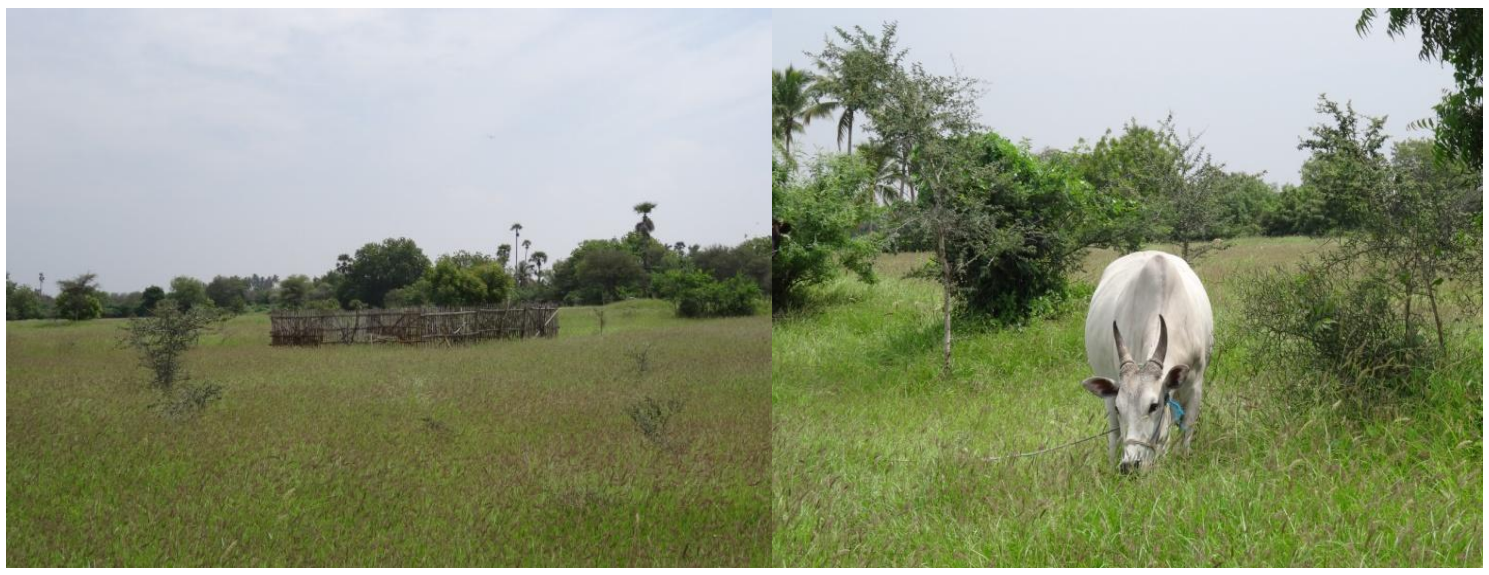




\section{Weakness}

Depends on monsoon

Initial growth is inadequate with external irrigation

Difficulty in maintenance of live fence

Problem in feeding during dry season

Biological predators

\section{Opportunity}

Conversion of waste land into useful pasture land

More suitable for dry land since the seeds tried were drought resistant

Establishment of pasture lands may reduce the dependency on agricultural labour

Increasing trend of rearing indigenous animals in conventional pattern

\section{Challenges faced}

Without understanding the fragile ecosystem with its very low groundwater table, many farmers are converting Korangadu lands into mono-croppings of cotton, maize, horticultural species etc., with deep bore wells (exceeding 300 meters) and establish industrial units. Younger generations are no longer interested in maintaining pure breeds of cattle. However, some are using their pasturelands for rearing sheep and crossbred milch animals (Parviz Koohafkan and Miguel A. Altieri, 2007).

So far, traditional grassland systems have not been incorporated into the mainstream watershed development programme. The announcement of a land ceiling by the government has discouraged farmers from keeping large areas of grazing land.

The pastureland development in private farm lands is crucial for sustaining the cattle breed.

Other threats are continuous failure of monsoon for 2-3 years, which leads to drying of the live fence. This in turn facilitates invading of other animals into the pastureland. There is also water scarcity caused by frequent drought. A parasite known as "Thangakodi" (Striga lutea) inhibits the growth of grass and leguminous plants. Severe infestation of Thangakodi causes reduction in the yield of grasses and legumes which results in great loss to the owners.

\section{Suggestive measures to be taken to improve Korangadu farming system}

Establishing Korangadu pasture land can be tried either if monsoon is abundant or adequate or with irrigation for growth and sustenance.

Involving a range of technologies to improve the productivity of grazing lands like reseeding with grasses, introduction of leguminous species, rotational grazing.

Porampok lands may be converted into pasture land

Korangadu pastureland is a good example of how a combination of grasses, legumes and trees has been well managed to maintain the health of a great diversity of livestock, which has been the basis for people's livelihood in the region. It can provide income security to resource poor families while at the same time enhancing the conservation of local livestock breeds. The local tenure system encourages landless families to access grasslands, which in turn sustain their livestock keeping and pastoral life. 


\section{References}

Akila, N and Bharathy, N. (2016). "SWOC of Korangadu pasture land for sheep" in Tamil Nadu, A time tested pasture land model. The North East Veterinarian, $\mathrm{XVI}(3), 1-16$.

Jayanthi, C and Mynavathi, V.S. (2012). Rainfed farming systems in Tamil Nadu: Resource characterization and management options to improve livelihood. Tamil Nadu Agricultural University, Coimbatore - 641 003, India.

Kumar, A, Natarajan, S, Biradar. N.B and Kumar B.K.T. (2011) Evolution Sedentary pastoralism in South India: case study of the Kangayam grassland. Pastoralism Research, Policy and Practice. 1:7. pp: 1-18.
Mahapatra, IC and Bapat, SR (1992). Farming systems research: Challenges and opportunities. Resource management for sustained crop production. In: Proc. XII National symposium of Indian Society of Agronomy. pp. 382-390.

Meena, L.R, Kochewad, S.A and Devendra Kumar. (2018). Improved Technologies for Sustaining Productivity and Profitability of Sheep in India-A Review. International Journal of livestock Research, 8(2), 43-55.

Parviz Koohafkan, Miguel A. Altieri. (2007). Forgotten Agricultural Heritage: Reconnecting Food Systems and Sustainable. pp: $153-155$.

Roy A.K. and Singh J.P. 2013. Grasslands in India: Problems and perspectives for sustaining livestock and rural livelihoods. Tropical Grasslands Forrajes Tropicales, 1: 240 - 243.

\section{How to cite this article:}

Bharathy, N., K. Sivakumar, V. Ramesh, D. Anandha Prakash Singh, K. Chinnamani and Clement Ebenezer Henry, A. 2018. "Korangadu"- Traditional Dry land Grass Farming System. Int.J.Curr.Microbiol.App.Sci. 7(08): 4390-4395. doi: https://doi.org/10.20546/ijcmas.2018.708.461 